ISSN 0258-7122

Bangladesh J. Agril. Res. 37(4): 635-644, December 2012

\title{
ROLE OF AMF ON PLANT GROWTH, NUTRIENT UPTAKE ARSENIC TOXICITY AND CHLOROPHYLL CONTENT OF CHILI GROWN IN ARSENIC AMENDED SOIL
}

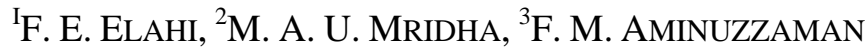

\begin{abstract}
Mycorrhizal fungi have their most significant effect on plant growth and have shown to reduce arsenic contamination to chili. The present experiment was carried out to determine the influence of AMF inoculation on plant growth, nutrient uptake, arsenic toxicity, and chlorophyll content of chili grown in arsenic amended soil. Chili was grown in arsenic amended soils with or without mycorrhizal inoculation. Three levels of arsenic concentrations (10 ppm, 100 ppm, and $500 \mathrm{ppm}$ ) were used. The seed germination was affected more by the two treatment variables. Root length, shoot height, root fresh weight, shoot fresh weight, root dry weight, shoot dry weight were higher in AMF inoculated plants in comparison to their respective treatments and decreased significantly with the increase rate of arsenic concentrations. Less arsenic content, higher chlorophyll, and nutrient uptake were recorded in mycorrhiza inoculated chili plants. The present findings indicated that AMP inoculation not only minimize arsenic toxicity, but also can increase growth and nutrient uptake of chili.
\end{abstract}

Keywords: Mycorrhizal fungi, arsenic contamination, chili.

\section{Introduction}

Arsenic (As) is a ubiquitous metalloid that is introduced into the environment from both anthropogenic and geochemical sources (Smith et al., 1998). In Bangladesh, arsenic contamination of groundwater is believed to cause arsenicrelated disorders in $80 \%$ of the population (Alam et al., 2002; Das et al., 2004). Arsenic can be introduced to food through plant uptake in soil contaminated by groundwater or irrigation water. Chili (Capsicum frutescence) contains Vit- A and Vit-C. It is a very popular and essential spice in our country. In Bangladesh, about 294245 acres of land was under chili (winter) cultivation and 22362 hectares of land was under summer variety cultivation. Moreover, total production for winter and summer varieties were about 130715 and 23240 metric tons, respectively (BBS, 2007). Arbuscular Mycorrhizal (AM) fungi are vital components of nearly all terrestrial ecosystems, forming mutually beneficial (mutualistic) symbiosis with the roots of around $80 \%$ of vascular plants and often increasing phosphate $(\mathrm{P})$ uptake and growth. Since the association is mutualistic,

\footnotetext{
${ }^{1}$ Scientific Officer, Plant Pathology Division, Bangladesh Agricultural Research Institute (BARI), Gazipur, ${ }^{2}$ Professor, Plant Production Department, King Saud University, Kingdom of Saudi Arabia, ${ }^{3}$ Assistant Professor, Department of Plant Pathology, Sher-e-Bangla Agricultural University (SAU), Dhaka, Bangladesh.
} 
both organisms take benefit from the association. The fungus receives carbohydrates (sugars) and growth factors from the plant, which in turn receives many benefits including increased nutrient absorption. In this association, the fungus takes over the role of the plant's root hairs and acts as an extension of the root system. Thus it increases the surface area of plant root systems, greatly facilitating uptake of soil water and nutrients, especially in harsh conditions. In particular AM fungi can greatly enhance the uptake of $\mathrm{Po}_{4}{ }^{+}$as well as $\mathrm{NH}_{4}{ }^{+}, \mathrm{K}^{+}$, and $\mathrm{NO}_{3}{ }^{-}$(Marschner and Dell, 1994; Hayman,1983). The external fungal hyphae act as a bridge transporting slow diffusing nutrients like P more effectively than those of non-mycorrhizal ones. As a chemical analogue of phosphate, arsenic competes with $\mathrm{P}$ in the soil and during plant uptake from the external because both elements are taken up via the phosphate transport systems (Meharg and Macnair, 1992; Cao et al., 2003). Recently, it has been demonstrated that mycorrhiza and phosphate fertilizers can protect plants grown in arsenic contaminated soils. The mechanisms proposed include the tolerance of higher plants to arsenate through down regulated arsenate/ phosphate transporters in the epidermis and root hairs (Meharg and Cairney, 1999; Gonzalez-Chavez et al., 2002), to reduce the uptake of arsenic, and up regulated low affinity of phosphate transporters located in the membrane fraction of mycorrhizal roots (Harrison et al., 2002), to take up more $\mathrm{P}$ for better growth. There is also growing evidence that mycorrhizal fungi may alleviate metal or metalloid toxicity to the host plant by acting as a barrier to uptake (Leyval et al., 1997). The underlying mechanism is thought to be the binding capacity of fungal hyphae which immobilize the metals in or near the roots and thus depresses translocation to the shoots (Bradley et al., 1981; Brown and Wilkins 1985; Wasserman et al., 1987). All the chemical and physical parameters show positive response to AMF inoculation. Moreover, higher nutrient uptake and less arsenic content are recorded in mycorrhiza inoculated plants (Saha, 2008). The objectives of the present study were set to assess the role of AMF on plant growth and nutrient uptake by chili and /or the interaction of arsenic and mycorrhiza on different physical and chemical growth parameters of chili plants.

\section{Materials and Method}

A survey was conducted in the agronomy field of Sher-e-Bangla Agricultural University in February 2008 to collect natural inoculum of mycorrhiza. Many root samples of different plants were stained according to Koske and Gemma (1989) with some modifications (Mridha et al., 1999). Among all the root samples, Leucas aspara showed the highest percentage of infection of mycorrhiza. For the preparation of $1000 \mathrm{ppm}$ arsenic solution, $4 \mathrm{~g}$ sodium hydroxide, $1.32 \mathrm{~g}$ arsenic powder and 10\% HC1 were used. 10 ppm, 100 ppm and $500 \mathrm{ppm}$ arsenic solution were prepared. $2 \mathrm{~kg}$ soil (in composition with $10 \%$ sand and $90 \%$ soil) was sterilized with $0.05 \%$ formaldehyde solution which was poured in poly bags mixing $25 \mathrm{~g}$ root inoculum and $100 \mathrm{~g}$ soil inoculum of 
mycorrhiza. Then arsenic solution of different concentrations (10 ppm, $100 \mathrm{ppm}$, and $500 \mathrm{ppm}$ ) was mixed with the poly bag soil and then the next day, chili seeds were sown in poly bags. The experiment was conducted following CRD with seven treatments $\left(T_{1}=\right.$ Control, $T_{2}=10 \mathrm{ppm}$ arsenic solution, $T_{3}=10 \mathrm{ppm}$ arsenic solution + mycorrhiza, $\mathrm{T}_{4}=100 \mathrm{ppm}$ arsenic solution, $\mathrm{T}_{5}=100 \mathrm{ppm}$ arsenic solution + mycorrhiza, $\mathrm{T}_{6}=500 \mathrm{ppm}$ arsenic solution, $\mathrm{T}_{7}=500 \mathrm{ppm}$ arsenic solution + mycorrhiza), and 5 replications. Data were recorded on seedling emergence (\%) (7 DAS, 10 DAS, and 15 DAS), shoot fresh and dry weight (g) (30 DAS, 45 DAS, and 60 DAS), root fresh and dry weight (g) (30 DAS, 45 DAS, and 60 DAS), shoot and root length (cm) (30 DAS, 45 DAs, and 60 DAS). Chemical analyses were done for the determination of P, K, S, N, and As by using Spectrophotometer, Flame photometer, micro-Kjeldahl method, and Hybrid Generation Atomic Absorption Spectrophotometer. Moreover, Chlorophyll content was determined with the help of Spectrophotometer by using this following formula:

Total chlorophyll=Absorbance (chlorophyll a+chlorophyll b) x Correction Factor

In this experiment, all data were analyzed in the computer using MSTAT package Program and mean difference was measured by DMRT.

\section{Results and Discussion}

\section{Seedling emergence}

Arsenic solution reduced seedling emergence of chili at 10 and 15 DAS in all the concentration tested (Table 1), but it increased when mycorrhiza was inoculated in the arsenic amended soil. The highest seedling emergence was recorded under the treatment T3 (100 ppm Arsenic + mycorrhiza) as compared to control. Very limited works have been done so far on response of seedling emergence of chili under different levels of soil As. Saha (2008) reported that AMF inoculation significantly increased seedling emergence of tomato and radish grown in arsenic contaminated soil. The findings of the present study are also supported by Akhter (2008).

\section{Shoot and root length}

The influence of AMF inoculation on shoot and root length of chili, seeds sown in soil amended soil with different concentrations of arsenic solution are shown in Table 2. The data were varied significantly at different concentrations. The shoot and root length were recorded at 30, 45 and 60 days after sowing. The highest shoot height was recorded in $\mathrm{T}_{3}$ treatment at $60 \mathrm{DAS}$. In case of root length the performance of mycorrhizal treatment $T_{3}(10 \mathrm{ppm}$ arsenic solution + mycorrhiza) was the best $(16.73 \mathrm{~cm}$ and $17.83 \mathrm{~cm}$ at 45 DAS and 60 DAS, respectively). The lowest root length of chili plant was recorded in treatment $T_{6}$ 
(500 ppm arsenic solution) and those were $12.33 \mathrm{~cm}$ and $14.40 \mathrm{~cm}$ at 45 DAS and 60 DAS, respectively. During those periods, the shoot and root lengths decreased with the increase of arsenic concentration. In most cases, the treatment $\mathrm{T}_{7}$ exhibited the lowest value. That is, shoot and root lengths decreased with increase of arsenic concentration. Present findings are in agreement with Matsubara et al. (1994) who investigated the effects of inoculation with vesicular-arbuscular mycorrhizal fungi (Glomus etunicatum or Glornus intraradices) on seedling growth of 17 vegetable crop species and reported that the growth was noticeably enhanced by VAMF inoculation to spinach, water spinach, Indian spinach, white gourd and cucumber.

Table 1. Influence of ANIF inoculation on seedling emergence of chili at different growth periods in soil amended with different concentrations of arsenic solution.

\begin{tabular}{l|r|r|r}
\hline \multirow{2}{*}{ Treatments } & \multicolumn{3}{|c}{ Seedling emergence } \\
\cline { 2 - 4 } & $7 \mathrm{DAS}$ & $10 \mathrm{DAS}$ & $15 \mathrm{DAS}$ \\
\hline $\mathrm{T}_{1}$ & $13.40 \mathrm{ab}$ & $13.40 \mathrm{ab}$ & $14.40 \mathrm{a}$ \\
$\mathrm{T}_{2}$ & $14.40 \mathrm{a}$ & $14.20 \mathrm{a}$ & $15.00 \mathrm{a}$ \\
$\mathrm{T}_{3}$ & $14.60 \mathrm{a}$ & $14.78 \mathrm{ab}$ & $17.00 \mathrm{a}$ \\
$\mathrm{T}_{4}$ & $9.400 \mathrm{ab}$ & $8.600 \mathrm{~b}$ & $14.80 \mathrm{a}$ \\
$\mathrm{T}_{5}$ & $13.20 \mathrm{ab}$ & $13.29 \mathrm{ab}$ & $15.00 \mathrm{a}$ \\
$\mathrm{T}_{6}$ & $7.20 \mathrm{c}$ & $13.37 \mathrm{ab}$ & $12.60 \mathrm{a}$ \\
$\mathrm{T}_{7}$ & $8.60 \mathrm{be}$ & $9.80 \mathrm{ab}$ & $12.40 \mathrm{a}$ \\
\hline LSD & 5.01 & 6.56 & $\mathrm{NS}$ \\
$\mathrm{CV}(\%)$ & 8.44 & 9.60 & 5.18 \\
\hline
\end{tabular}

DAS $=$ Days After Sowing

$\mathrm{T}_{1}=$ Control, $\mathrm{T}_{2}=10 \mathrm{ppm}$ arsenic solution, $\mathrm{T}_{3}=10 \mathrm{ppm}$ arsenic solution + mycorrhiza, $\mathrm{T}_{4}=100 \mathrm{ppm}$ arsenic solution, $\mathrm{T}_{5}=100 \mathrm{ppm}$ arsenic solution + mycorrhiza, $\mathrm{T}_{6}=500$ ppm arsenic solution, $\mathrm{T}_{7}=500 \mathrm{ppm}$ arsenic solution + mycorrhiza

\section{Fresh and dry weight of shoot and root}

The influence of AMF inoculation on fresh and dry weight of shoot and root of chili at different growth periods in soil amended with different concentrations of arsenic solution are presented in Table 3. The highest fresh weight of chili shoot was recorded in treatment $T_{3}$ followed by treatment $T_{2}, T_{5}$ and the lowest was recorded in treatment $\mathrm{T}_{7}$ at 30 DAS, 45 DAS and 60 DAS. On the other hand, treatment $\mathrm{T}_{3}(10 \mathrm{ppm}$ arsenic solution + mycorrhiza ) gave the highest value in case of fresh weight of root and those were $3.77 \mathrm{~g}, 4.16 \mathrm{~g}$ and $6.17 \mathrm{~g}$ at 30 DAS, 
45 DAS and 60 DAS, respectively, which is significantly better compared to the other treatments. Similar results were reported by Tarafdar and Parveen (1996). In case of treatment $T_{2}$ and $T_{4}$, it clearly showed that with the increase of arsenic concentration, the fresh weight of shoot and fresh weight of root of chili decreased. In case of only As treatment 12 (10 ppm arsenic solution), the fresh weight of shoot and root of chili at 60 DAS was $11.14 \mathrm{~g}$ and $2.88 \mathrm{~g}$, respectively, but increased up to $3.18 \mathrm{~g}$ and $6.17 \mathrm{~g}$ when mycorrhiza was inoculated with 10 ppm As solution. Fresh weight of shoot and root increased when the plants were inoculated with AMF (Matsurba et al., 1994). Dry weight of shoot and root of chili at 60 DAS was highly significant for treatment $\mathrm{T}_{3}(10 \mathrm{ppm}$ Aresnic solution + Mycorrhiza) followed by $\mathrm{T}_{5}$ (100 ppm Arsenic solution + mycorrhiza) whereas, dry weight shoot and root was the lowest in treatment $T_{2}$ (10 ppm Arsenic solution). At 30, 45, and 60 DAS, the shoot dry weight of chili were $3.28 \mathrm{~g}, 3.62$ $\mathrm{g}$ and $4.35 \mathrm{~g}$, respectively, and the root dry weight of chili were $1.07 \mathrm{~g}, 1.29 \mathrm{~g}$, and $2.34 \mathrm{~g}$ over the same DAS which corroborate with the findings of Carling and Brown (1980). A similar result was also reported by Agely et al. (2005). He found that the AM fungi not only tolerate arsenic amendment, but their presence increased dry mass at the highest arsenic application rate.

\section{Nutrient uptake, arsenic concentration and chlorophyll content}

The inoculation of Arbuscular mycorrhizal fungi in response to nutrient uptake $(\mathrm{N}, \mathrm{P}, \mathrm{K}$, and S), arsenic uptake and chlorophyll content by chili shoots at 60 DAS is represented in Table 4. The highest nutrient uptake was recorded in treatment T3 (10 ppm Arsenic solution + mycorrhiza) and those were $2.33 \%$ total N, $2.03 \% \mathrm{P}, 1.38 \% \mathrm{~K}$ and $1.21 \% \mathrm{~S}$ and the lowest result was found in treatment 16 (500 ppm Arsenic solution) and those were $1.41 \%$ total N, $0.99 \%$ $\mathrm{P}, 0.69 \% \mathrm{~K}$ and $0.14 \% \mathrm{~S}$. The lowest amount of arsenic was found in treatment T3 (10 ppm arsenic solution + mycorrhiza) and that was $89.67 \mathrm{ppm}$ on the other hand the highest amount was found in treatment $\mathrm{T}_{5}$ (500 ppm arsenic solution) and that was $289.3 \mathrm{ppm}$. Between the treatment $\mathrm{T}_{2}$ and $\mathrm{T}_{3}$, the amount of arsenic was higher in treatment $\mathrm{T}_{2}$ and that was $251.3 \mathrm{ppm}$ but inoculation of mycorrhiza on that treatment the amount decreased significantly to $89.67 \mathrm{ppm}$. In addition, In case of chlorophyll content by shoots of chili the lowest amount of chlorophyll was found in treatment $\mathrm{T}_{7}$ (500 ppm arsenic solution + mycorrhiza) followed by treatment $\mathrm{T}_{6}$ ( $500 \mathrm{ppm}$ Arsenic solution) whereas, in treatment $\mathrm{T}_{3}(10 \mathrm{ppm}$ arsenic solution + mycorrhiza) chlorophyll content was $0.4197 \mathrm{ppm}$ which is the highest in compared to other treatments. Similar result was reported by Dong et al. (2007). VAM fungi inoculation increases nutrient absorption is also supported by Khan at el. (1995). 
Table 2. Influence of AMF inoculation on shoot height and root length of chili at different growth periods in soil amended with different concentrations of arsenic solution.

\begin{tabular}{|c|c|c|c|c|c|c|}
\hline \multirow{2}{*}{ Treatments } & \multicolumn{3}{|c|}{ Shoot height ( cm) } & \multicolumn{3}{|c|}{ Root length (cm) } \\
\hline & 30 DAS & 45DAS & 60DAS & 30 DAS & 45 DAS & 60 DAS \\
\hline $\mathrm{T}_{1}$ & $18.97 \mathrm{~b}$ & 18.73 c & $20.73 a b$ & $13.00 \mathrm{~b}$ & $13.90 \mathrm{bc}$ & $14.43 b$ \\
\hline $\mathrm{T}_{2}$ & 17.60 bc & 17.37 c & $17.83 \mathrm{c}$ & $12.40 \mathrm{~cd}$ & $14.40 \mathrm{bc}$ & $15.07 \mathrm{~b}$ \\
\hline $\mathrm{T}_{3}$ & $13.73 \mathrm{~d}$ & $18.97 \mathrm{bc}$ & $22.20 \mathrm{a}$ & $15.70 a$ & 16.73 a & $17.83 \mathrm{a}$ \\
\hline $\mathrm{T}_{4}$ & $16.23 \mathrm{c}$ & $18.03 \mathrm{c}$ & $18.03 c$ & $10.87 d$ & $13.33 \mathrm{bc}$ & $17.67 a$ \\
\hline $\mathrm{T}_{5}$ & 22.37 a & 20.77ab & $19.60 \mathrm{bc}$ & $14.33 \mathrm{ab}$ & $14.90 \mathrm{ab}$ & $15.13 \mathrm{~b}$ \\
\hline $\mathrm{T}_{6}$ & $22.70 \mathrm{a}$ & $21.43 \mathrm{a}$ & $19.80 \mathrm{abc}$ & $11.50 \mathrm{~cd}$ & 12.33 c & $14.40 \mathrm{~b}$ \\
\hline $\mathrm{T}_{7}$ & $19.43 \mathrm{~b}$ & $19.00 \mathrm{bc}$ & 18.57 bc & $12.23 \mathrm{~cd}$ & $12.90 \mathrm{bc}$ & $14.40 \mathrm{~b}$ \\
\hline LSD & 1.838 & 1.827 & 2.325 & 1.822 & 2.067 & 2.227 \\
\hline CV (\%) & 5.55 & 6.67 & 3.44 & 5.84 & 3.34 & 6.34 \\
\hline
\end{tabular}

DAS $=$ Days After Sowing

$\mathrm{T}_{1}=$ Control, $\mathrm{T}_{2}=10 \mathrm{ppm}$ arsenic solution, $\mathrm{T}_{3}=10 \mathrm{ppm}$ arsenic solution + mycorrhiza, $\mathrm{T}_{4}=100 \mathrm{ppm}$ arsenic solution, $\mathrm{T}_{5}=100 \mathrm{ppm}$ arsenic solution+ mycorrhiza, $\mathrm{T}_{6}=500 \mathrm{ppm}$ arsenic solution, $\mathrm{T}_{7}=500 \mathrm{ppm}$ arsenic solution + mycorrhiza 
Table 3. Influence of AMF inoculation on fresh and dry weight of shoot and root of chili at different growth periods in soil amended with different concentrations of arsenic solution.

\begin{tabular}{|c|c|c|c|c|c|c|c|c|c|c|c|c|}
\hline \multirow[t]{3}{*}{ Treatments } & \multicolumn{3}{|c|}{$\begin{array}{c}\text { Fresh weight of shoot } \\
\qquad\left({ }^{\mathrm{g}}\right)\end{array}$} & \multicolumn{3}{|c|}{$\begin{array}{l}\text { Fresh weight of root } \\
\text { (g) }\end{array}$} & \multicolumn{3}{|c|}{$\begin{array}{l}\text { Dry weight of shoot } \\
\text { (g) }\end{array}$} & \multicolumn{3}{|c|}{$\begin{array}{l}\text { Dry weight of root } \\
\text { (g) }\end{array}$} \\
\hline & 30 & 45 & 60 & 30 & 45 & 60 & 30 & 45 & 60 & & 45 & 60 \\
\hline & DAS & DAS & DAS & DAS & DAS & DAS & DAS & DAS & DAS & 30 DAS & DAS & DAS \\
\hline $\mathrm{T}_{1}$ & $9.677 \mathrm{~d}$ & $10.54 \mathrm{~cd}$ & $11.33 \mathrm{c}$ & $2.96 \mathrm{a}$ & $3.26 \mathrm{abc}$ & $4.39 \mathrm{~b}$ & $2.53 \mathrm{ab}$ & 3.18 a & $3.70 \mathrm{abc}$ & $0.89 \mathrm{ab}$ & $0.97 \mathrm{ab}$ & $1.96 \mathrm{ab}$ \\
\hline $\mathrm{T}_{2}$ & $8.567 \mathrm{~d}$ & $9.363 \mathrm{~d}$ & $11.14 \mathrm{c}$ & $2.80 \mathrm{a}$ & $4.02 \mathrm{ab}$ & 3.47 bc & $2.32 \mathrm{abc}$ & $2.38 \mathrm{~b}$ & $2.53 \mathrm{~d}$ & $0.58 \mathrm{~b}$ & $0.85 \mathrm{ab}$ & $1.63 \mathrm{~b}$ \\
\hline $\mathrm{T}_{3}$ & $25.60 \mathrm{a}$ & 29.33 a & 31.83 a & 3.77 a & $4.16 \mathrm{a}$ & $6.17 \mathrm{a}$ & $3.28 \mathrm{a}$ & $3.62 \mathrm{a}$ & $4.35 \mathrm{a}$ & $1.07 \mathrm{a}$ & $1.29 \mathrm{a}$ & 2.34 \\
\hline $\mathrm{T}_{4}$ & $12.96 \mathrm{c}$ & $4.60 \mathrm{bc}$ & $15.37 \mathrm{bc}$ & $2.55 a$ & $2.60 \mathrm{c}$ & $2.50 \mathrm{c}$ & $2.38 \mathrm{abc}$ & $2.74 \mathrm{~b}$ & $3.56 \mathrm{bc}$ & $0.53 \mathrm{~b}$ & $0.91 \mathrm{ab}$ & $1.45 \mathrm{~b}$ \\
\hline $\mathrm{T}_{5}$ & $18.29 \mathrm{~b}$ & $16.61 \mathrm{~b}$ & $20.45 b$ & $2.83 \mathrm{a}$ & 2.95 bc & $3.66 \mathrm{bc}$ & $2.71 \mathrm{ab}$ & $2.97 \mathrm{ab}$ & $3.22 \mathrm{~cd}$ & $0.59 \mathrm{~b}$ & $0.77 \mathrm{~b}$ & $1.34 \mathrm{~b}$ \\
\hline $\mathrm{T}_{6}$ & $8.523 \mathrm{~d}$ & $9.490 \mathrm{~d}$ & 15.19be & $2.59 \mathrm{a}$ & $3.26 \mathrm{abc}$ & 3.62 bc & 1.38 c & $2.45 \mathrm{~b}$ & $4.11 \mathrm{ab}$ & $0.85 \mathrm{ab}$ & $0.88 \mathrm{~b}$ & $1.50 \mathrm{~b}$ \\
\hline $\mathrm{T}_{7}$ & $4.780 \mathrm{e}$ & $7.390 \mathrm{~d}$ & $10.96 \mathrm{c}$ & $2.76 \mathrm{a}$ & 2.95 be & $3.06 \mathrm{c}$ & 1.96 be & $2.99 \mathrm{ab}$ & $2.70 \mathrm{~d}$ & $0.89 \mathrm{ab}$ & $0.78 \mathrm{~b}$ & $1.50 \mathrm{~b}$ \\
\hline LSD & 1.465 & 4.496 & 5.733 & NS & 1.072 & 1.214 & 0.946 & 0.799 & 0.7026 & 0.3280 & 0.450 & 0.592 \\
\hline CV (\%) & 6.52 & 8.82 & 4.45 & 9.10 & 8.80 & 7.59 & & & & 5.04 & 4.45 & 3.98 \\
\hline
\end{tabular}

DAS $^{=}$Days After Sowing

$\mathrm{T}_{1}=$ Control, $\mathrm{T}_{2}=10 \mathrm{ppm}$ arsenic solution, $\mathrm{T}_{3}=10 \mathrm{ppm}$ arsenic solution + mycorrhiza, $\mathrm{T}_{4}=100 \mathrm{ppm}$ arsenic solution, $\mathrm{T}_{5}=100 \mathrm{ppm}$ arsenic solution+ mycorrhiza, $\mathrm{T}_{6}=500 \mathrm{ppm}$ arsenic solution, $\mathrm{T}_{7}=500 \mathrm{ppm}$ arsenic solution+ mycorrhiza 
Table 4. Influence of AMF inoculation on nutrient uptake, arsenic uptake and chlorophyll content at harvest of chili at 60 DAS in soil amended with different concentrations of arsenic solution.

\begin{tabular}{|c|c|c|c|c|c|c|}
\hline \multirow{2}{*}{ Treatments } & \multicolumn{4}{|c|}{ Nutrient uptake } & \multirow{2}{*}{$\begin{array}{c}\text { Arsenic } \\
\text { (As) } \\
\text { (ppm) }\end{array}$} & \multirow{2}{*}{$\begin{array}{c}\text { Chlorophyll } \\
\text { content }\end{array}$} \\
\hline & Total N \% & $\mathrm{p} \%$ & K \% & S \% & & \\
\hline $\mathrm{T}_{1}$ & 1.86 be & $1.13 \mathrm{~b}$ & $0.91 \mathrm{ab}$ & $1.04 \mathrm{~b}$ & $161.7 \mathrm{a}$ & $0.1570 \mathrm{a}$ \\
\hline $\mathrm{T}_{2}$ & $1.54 \mathrm{~cd}$ & $1.16 \mathrm{~b}$ & $1.35 \mathrm{a}$ & $0.29 \mathrm{ab}$ & $89.67 b$ & 0.4063 a \\
\hline $\mathrm{T}_{3}$ & 2.33 a & $2.03 \mathrm{a}$ & $1.38 \mathrm{a}$ & $1.21 \mathrm{a}$ & $126.7 \mathrm{~b}$ & 0.4197 a \\
\hline $\mathrm{T}_{4}$ & $2.06 \mathrm{ab}$ & $1.43 \mathrm{~b}$ & $1.06 \mathrm{ab}$ & $0.67 \mathrm{ab}$ & $251.3 \mathrm{~b}$ & 0.2680 a \\
\hline $\mathrm{T}_{5}$ & $1.80 \mathrm{bc}$ & $1.16 \mathrm{~b}$ & $0.70 \mathrm{~b}$ & $0.58 \mathrm{ab}$ & $289.3 \mathrm{a}$ & 0.1550 a \\
\hline $\mathrm{T}_{6}$ & $1.41 \mathrm{~d}$ & $0.99 \mathrm{~b}$ & $0.69 \mathrm{~b}$ & $0.14 \mathrm{~b}$ & $116.0 \mathrm{a}$ & $0.1460 \mathrm{a}$ \\
\hline $\mathrm{T}_{7}$ & $1.66 \mathrm{~cd}$ & $1.40 \mathrm{~b}$ & $0.78 \mathrm{~b}$ & $0.45 \mathrm{ab}$ & $61.52 \mathrm{a}$ & $0.1340 \mathrm{a}$ \\
\hline LSD & 0.3468 & 0.4605 & 0.4394 & 0.9414 & 0.5634 & NS \\
\hline CV (\%) & 8.81 & 6.21 & 2.89 & 7.76 & $161.7 \mathrm{~A}$ & 8.20 \\
\hline
\end{tabular}

DAS= Days After Sowing

$\mathrm{T}_{1}=$ Control, $\mathrm{T}_{2}=10 \mathrm{ppm}$ arsenic solution, $\mathrm{T}_{3}=10 \mathrm{ppm}$ arsenic solution + mycorrhiza, $\mathrm{T}_{4}=100 \mathrm{ppm}$ arsenic solution, $\mathrm{T}_{5}=100 \mathrm{ppm}$ arsenic solution + mycorrhiza, $\mathrm{T}_{6}=500 \mathrm{ppm}$ arsenic solution, $\mathrm{T}_{7}=500 \mathrm{ppm}$ arsenic solution + mycorrhiza

\section{Conclusion}

Bangladesh is one of the most densely populated countries and crop production needs to be increased through low inputs method. Mycorrhizal technology would be least expensive, simple, and nature farming technology. Increased crop production and decreased arsenic toxicity of chili has particularly importance for human health and suggests that mycorrhizal inoculation may contribute to minimize arsenic through consumption of chili grown in arsenic contaminated areas of Bangladesh.

\section{References}

Agely, A. A., D.M. Sylvia, and L.Q. Ma. 2005. Mycorrhizae increase arsenic uptake by the hyperaccumulator Chinese brake fern (Pteris vittata L.). J. Environ. Qual. 34(6): 2181-2186.

Akther, B. 2008. Mycorrhizal status of crops grown in arsenic affected areas of Sonargaon and influence of mycorrhizae on growth of selected crops in arsenic amended soil. M.S. Thesis. Department of Plant Pathology, Sher-eBangla Agricultural University, Dhaka. 
Alam, M.G., G. Allinson., F. Stagnitti., A. Tanaka, and M. Westbrooke. 2002. Arsenic contamination in Bangladesh groundwater: A major environmental and social disaster. Int. J. Environ. Health Res. 12: 235-253.

BBS (Bangladesh Bureau of Statistics). 2007. Monthly Statistical Bulletin, June. Ministry of Planning, Government of the People's Republic of Bangladesh, Dhaka, pp. 66-67.

Bradley, R., A. J. Burt, and D. J. Read. 1981. Mycorrhizal infection and resistance to heavy metal toxicity in Calluna vulgaris. Nature 292: 335337.

Brown, M. T. and D. A. Wilkins, 1985. Zinc tolerance of mycorrhizal Betula. New Phytol. 99: 101-106.

Cao, X., L. Q. Ma, and A. Shiralipour, 2003. Effects of compost and phosphate amendments on arsenic mobility in soils and arsenic mobility in soils and arsenic uptake by the hyper accumulator pteris vitata L. Environ Pollut. 126: $157-167$.

Carling, D.E. and Brown, M.F. 1980. Relative effect of vesicular mycorrhizal fungi on growth and yield of soyabeans. Soil. Sci. Soic. America. J. 44(3): 528-592.

Das, H.K., A. K. Mitra., A. Hossain., F. Isalm, and G. H. Rabbani. 2004. Arsenic concentrations in rice, vegetables and fish in Bangladesh: a preliminary study. Environ. Int. 30: 383-387.

Dong, Y., Y. G. Zhu., F. A. Smith, Y. Wang, and B. Chen. 2007. Arbuscular mycorrhiza enhanced arsenic resistance of both white clover (Trifolium repens Linn.) and ryegrass (Lolium perenne L.) plants in an arseniccontaminated soil. Department of Soil Environmental Science, Research Center for Eco-Environmental Sciences, the Chinese Academy of Sciences, 18 Shuangqing Road, Beijing 100085, China.

Gonzalez, C.C., P. J. Harris, and J. Dodd. 2002. Arbuscular mycorrhizal fungi confer enhanced arsenate resistance on Holcus lanatus. New Phytol. 155: 163-171.

Harrison, M.J., G. R. Dewbre, and J. Liu, 2002. A phosphate transporter from Medicago trunculata involved in the acquisition of phosphate released by arbuscular mycorrhizal fungi. Plant Cell. 14: 1-17.

Hayman, D.S. 1983. The physiology of vesicular-arbuscular endomycorrhizal symbiosis. Can. J. Bot. 61(3). P. 944-963.

Khan, M.K., K. Sakamoto, and T. Yoshida, 1995. Dual inoculation of ground nut with Glomus sp. and Bradyrhizobium sp. enhanced the symbiotic nitrogen fixation assessed by $15 \mathrm{~N}$-technique. Soil Sci. P1. Nutri. 41(4): 769-779.

Koske, R. E. and J. N. Gemma, 1989. A modified procedure for staining roots to detect VA-mycorrhizas. Mycol. Res. 92: 486-488. 
Leyval, C., Turnau, K. and Haselwandter, K. 1997. Effect of heavy metal pollution on mycorrhizal colonization and function: physiological, ecological and applied aspects. Mycorrhzia. 7: 139-153.

Marschner, H. and B. Dell, 1994. Nutrient uptake in mycorrhizal symbiosis. Plant Soil. 159: 89-102.

Matsubara, V. I., T. Haraba, and T. Yakuwa. 1994. Effect of vesicular-arbuscular mycorrhizal fungi inoculation on seedling growth in several species of vegetable crops. J. Jap. Soci. Hort. Sci. 63(3): 619-628.

Meharg, A. A. and M. R. Macnair, 1992. Suppression of the high affinity phosphate uptake system: a mechanism of arsenic tolerance in Holcus lanatus L. J. Exp. Bot. 43: 519-524.

Meharg, A.A. and J. W. G. Cairney. 1999. Co-evolution of mycorrhizal symbionts and their hosts to metal contaminated environments. Adv. Ecol. Res. 30: 70-112.

Mridha, M. A. U., A. Sultana., N. Sultana., H. L. Xu, and H. Umemura. 1999. Biodiversity of VA mycorrhizal fungi of some vegetable crops in Bangladesh. Proc. International Symposium on World Food Security and Crop Production Technologies for Tomorrow, October 8-9,1998. Kyoto, Japan 330-331.

Saha, N. K. 2008. Mycorrhizal status of crops grown in arsenic affected areas of Manikganj district and effect of mycorrhiza on growth of some crops in arsenic amended soil. M.S. Thesis. Dept. of Pl. path. Sher-e-Bangla Agricultural University, Bangladesh.

Smith, E., R. Naidu, and A. M. Alston. 1998. Arsenic in the soil environment: A review. Adv. Agron. 64: 149-195.

Tarafdar, J. C. and K. Praveen, 1996. The role of Vesicular Arbuscular Mycorrhizal fungi on crop, tree and grasses grown in an arid environment. J. of Arid Environment 34: 197-203.

Wassermann, J. L., Mineo, L., Majumdar, S. K. and Vantyne, C. 1987. Detection of heavy metals in oak mycorrhizae of northeastern Pennsylvania forests, using X-ray microanalysis. Canadian J. Bot. 65: 2622-2627. 